\title{
Effect of Nutrient Management on Growth, Productivity and Quality of Oats with Special Emphasis on Zinc \& Boron
}

\author{
Shreeparna Saha ${ }^{1}$, Tanmoy Shankar ${ }^{2 *}$ and Arun Kumar Barik ${ }^{1}$ \\ ${ }^{1}$ Palli Siksha Bhavana, Visva-Bharati, Sriniketan, Birbhum, West Bengal, India \\ ${ }^{2}$ Department of Agronomy, M.S. Swaminathan School of Agriculture, Centurion University Technology and Management, \\ Paralakhemundi, Odisha, India
}

*Corresponding author: tanmoy.shankar125@gmail.com

Received: $21-12-2019$

Revised: $15-04-2020$

Accepted: 25-05-2020

\begin{abstract}
A field experiment was conducted during rabi season of 2011-12 at agricultural research farm, Palli Siksha Bhavana (Institute of Agriculture), Visva-Bharati, Sriniketan, West Bengal to study the effect of nutrient management on seed production of oats with special emphasis on zinc \& boron. The experiment was laid out in randomized block design having twelve treatments with each treatment replicated thrice. The use of 100\% NPK + FYM @ 10t / ha + ZnSO @ 20 kg / ha + Borax @10 kg/ha showed the highest growth attributes such as no. of tillers/ plant, dry matter accumulation. This was at par with the application of 100\% NPK+FYM@10 t/ ha+ ZnSO and Borax at their lower levels (@ 10 kg and 5 kg per ha, respectively). Yield components like number of filled grains / panicle, percent filled grains and test weight of oats seeds were non-significant except number of panicles/ m². Application of 100\% NPK+FYM@ 10 t/ ha+ $\mathrm{ZnSO}_{4}$ @ $20 \mathrm{~kg} /$ ha+Borax@ $10 \mathrm{~kg} /$ ha produced the highest no. of panicles $/ \mathrm{m}^{2}$ which was significantly higher than all other treatments. The highest grain yield, straw yield and biological yield were achieved from the treatment with 100\% NPK+FYM@10 t/ ha+ ZnSO @ 20 kg/ha+ Borax @ 10 kg/ ha. With respect to seed quality of oats, combined application of $\mathrm{ZnSO}_{4}$ and Borax at their higher rates $(20 \mathrm{Kg}$ and $10 \mathrm{~kg} / \mathrm{ha}$, respectively) along with 100\% NPK+FYM@ 10 t/ha exhibited the highest nitrogen content (\%) and crude protein percent. This treatment produced significantly higher crude protein yield than other treatments. Length, breadth and length: breadth ratio of oats was not influenced significantly by the treatments, it was found that combined application of $\mathrm{ZnSO}_{4}$ and Borax at their higher rates i.e., $20 \mathrm{Kg}$ and $10 \mathrm{~kg} / \mathrm{ha}$, respectively along with 100\% NPK and FYM@ 10t/ha showed the highest content of N.
\end{abstract}

Keywords: Oats, Farm yard manure, $\mathrm{ZnSO}_{4}$ and Borax

The common oat (Avena sativa) is a cereal grain grown for its seed, feed and fodder. Oats typically make up a part of the daily diet of domestic uses for horses, about $20 \%$ of daily intake or smaller, and are regularly fed to cattle, as well. Oats are also used in some brands of pet food for dog and chicken feed. Oat seeds are commonly marketed as cat grass to cat enthusiasts, since cats readily, Oat seeds are commonly marketed as cat grass to cat enthusiasts, since cats readily, harvest and eat tender young oat, wheat, and a few other grass sprouts. Agriculture and farming in India are interwoven with the intricate fabric of the society in cultural, religious and economical ways as farming and livestock rearing forms an integral part of rural living. India supports nearly $20 \%$ of the World's livestock and $16.8 \%$ of human population with only $2.3 \%$ of the World's geographical area. It indicates the pressure of

How to cite this article: Saha, S., Shankar, T. and Barik, A.K. (2020). Effect of Nutrient Management on Growth, Productivity and Quality of Oats with Special Emphasis on Zinc \& Boron. International Journal of Bioresource Science, 7(1): 25-31.

Source of Support: None; Conflict of Interest: None 
animal on its limited land resources. Although the contribution of agricultural sector in Indian economy is steadily declining (from 36.4\% in 198283 to $18.5 \%$ in (Anonymous 2011), the agriculture and livestock sector still provides employment to $52 \%$ of the work force. India has a about livestock population of over 343 million. But we are highly deficient in various livestock products through we have about one-fourth of the total cattle population of the world. The reason of low productivity of our livestock is malnutrition, under-nutrition or both. So, continuous supply of green fodder or feed is essential for obtaining sustainable productivity of animals as well as animal products for feeding the ever increasing human population. But due to population pressure of human, arable land is mainly used for food and cash crop. The productivity of cultivated fodder is also low because of less input use and less availability of good quality seeds of improved cultivar. In India, less than $5 \%$ of total cultivated land is under fodder production. Accordingly, the availability of green and dry fodder is in deficit on an average to the extent of 53 per cent (Jena et al. 2019) which may further increase to the extent of 65 per cent in 2025.

In West Bengal, $1.18 \%$ of cultivated area is under fodder production where as in Birbhum district the situation is miserable i.e., $0.7 \%$ of the cultivated area. Requirement of green fodder in West Bengal is 93 million tonnes where as the availability is only 1.9 million tonnes with a deficit of 91 million tonnes. Extension of improved fodder production technology especially availability and use of improved cultivars of different crops have yet to reach to the farmers in significant way. The major limitation is the organized production, marketing and distribution. The productivity and availability of forage seeds are important because the crops have been bred sustainability for fodder purpose and as such they are shy seeders with very low in seed productivity.

The growers of seed aim to grow good seed of species and varieties that are in demand and to achieve economical production. The more widespread use of improved varieties of forage will depend upon the continuous availability of seed or planting material which is true to the type, free from weed which will give good production on cultivation. Mostly green fodder is used for feeding the animal in green stage, so they are not allowed to produce seed. Moreover, the non- availability of forage seed in right time results in less area under forage seed production. The farmers have to depend on other sources like private organization and other states. Seed production of oats will mitigate the deficiency of green fodder production (Deise et al. 2012), Oats seeds can also be used for human consumption. Oats have numerous uses in food and most commonly considered 'health food', being touted commercially as nutritious. The discovery of the cholesterol lowering properties has led to wider appreciation of oats as human food and possibly reduces the risk of heart disease. Oat content protein content of the hull-less oat kernel ranges from 12 to $24 \%$, the Riboflavin (Vit. B2) 0.139 mg, (12\%), Niacin (Vit. B3) $0.961 \mathrm{mg}$ (6\%), Pantothenic acid (B5) 1.349 mg, (27\%) Folate (Vit. B9) $56 \mu \mathrm{g}$ (14\%), Calcium $54 \mathrm{mg}$ (5\%) Iron $5 \mathrm{mg}$ (38\%), Magnesium $177 \mathrm{mg}$ (50\%), Manganese $4.9 \mathrm{mg}$ (233\%), Phosphorus 523 $\mathrm{mg}$ (75\%), Potassium $429 \mathrm{mg}$ (9\%), Zinc $4 \mathrm{mg}$ (42\%), $\beta$-glucan (soluble fibre) $4 \mathrm{~g}$ Percentages are relative to United State recommendations for adults (Singh 2009).

Application of various micro-nutrients like $\mathrm{Zn}$ involve in the synthesis of tryptophan, which is a precursor of indol acetic acid (IAA) and is required for plant growth, nitrogen metabolism, starch and chlorophyll synthesis and ATPase activity, as well as the transport of assimilates (Malta et al. 2002), B on seed production of oats not only improve the quality of oats seed but also reduce the deficiency of micro-nutrients in animals in absence of which the animals may suffer from malnutrition and various disorders as Boron is responsible for the cell wall synthesis and lignifications (Goldbach et al. 2001). Crop yield even when sown in micronutrient deficit soils and agronomically it reduces seed rates, resulting in substantial economic saving on input cost. Micronutrients enriched fodders and grain concentrate are beneficial in livestock production. However, there is currently a resurgence of interest in the crop owing to considerable scientific evidence to support its use as food, feed and fodder. Keeping all these ideas in view the present experiment was carried out for special emphasis on zinc and boron.

\section{MATERIALS AND METHODS}

The experiment was conducted during rabi season 
of 2011-2012 at Agricultural Farm, Palli Siksha Bhavana, Visva-Bharati, Sriniketan,West Bengal in red and lateritic soil. The farm was situated at $23^{\circ} 39^{\prime} \mathrm{N}$ latitude and $87^{\circ} 42^{\prime} \mathrm{E}$ longitude under sub-humid, semi-arid region of West Bengal. The experiment, consisting of twelve treatments, was laid out in Randomized Block Design (RBD) with each treatment replicated thrice. The treatment $\mathrm{T}_{1}: 100 \%$ NPK (80:40:20; $\mathrm{N}: \mathrm{P}_{2} \mathrm{O}_{5}: \mathrm{K}_{2} \mathrm{O}$ in $\left.\mathrm{kg} / \mathrm{ha}\right)$, $\mathrm{T}_{2}: 100 \% \mathrm{NPK}+\mathrm{FYM} @ 10 \mathrm{t} / \mathrm{ha}, \mathrm{T}_{3}: 100 \% \mathrm{NPK}+$ $\mathrm{ZnSO}_{4} @ 10 \mathrm{~kg} / \mathrm{ha} \mathrm{T}_{4}: 100 \% \mathrm{NPK}+\mathrm{ZnSO}_{4} @ 20 \mathrm{~kg} /$ ha, $\mathrm{T}_{5}: 100 \%$ NPK+FYM @ $10 \mathrm{t} / \mathrm{ha}+\mathrm{ZnSO}_{4} @ 10 \mathrm{~kg} /$ ha, $\mathrm{T}_{6}: 100 \%$ NPK+ FYM @ $10 \mathrm{t} / \mathrm{ha}+\mathrm{ZnSO}_{4} @ 20 \mathrm{~kg} /$ ha, $\mathrm{T}_{7}: 100 \%$ NPK + Borax@ $5 \mathrm{~kg} / \mathrm{ha}, \mathrm{T}_{8}: 100 \%$ NPK +Borax@10 kg/ha, T:100\% NPK+ FYM @ 10 t/ha + Borax@ 5 kg/ha, T 10 :100\% NPK+ FYM @ 10 t/ha + Borax@10 kg/ha, T $: 100 \%$ NPK+ FYM @ 10 t/ha + ZnSO $@ 10$ kg/ha + Borax@ 5 kg/ha, T $12: 100 \%$ NPK+ FYM@10 t/ha+ZnSO @ 20 kg/ha + Borax@10 kg/ha. The fodder crop oat var. JHO-822, a multi-cut fodder variety was grown during rabi (winter) season of 2011-2012. The harvesting of oats was done after 120 DAS. The Land preparation at optimum moisture condition the land was ploughed twice by tractor drawn harrow thoroughly for obtaining good tilth.

The oat variety JHO-822 was sown with a seed rate of $100 \mathrm{~kg} / \mathrm{ha}$ with row to row spacing of $25 \mathrm{~cm}$ and continuous sowing within the row at a soil depth of $5 \mathrm{~cm}$. Well decomposed farm yard manure was applied in experimental plot as per treatment and incorporated into the soil thoroughly three week before sowing of the crop. Chemical fertilizers such as nitrogen, phosphorus $\left(\mathrm{P}_{2} \mathrm{O}_{5}\right)$ and potassium $\left(\mathrm{K}_{2} \mathrm{O}\right)$ were applied from Urea, Single Super Phosphate (SSP) and Muriate of Potash (MOP) respectively as per treatment. Two third quantity of nitrogen and full quantity of phosphorus and potassium were applied as basal during sowing time. Borax and $\mathrm{ZnSO}_{4}$ were also applied as basal during the time of sowing as per treatment. Rest one third quantity of nitrogen was top dressed at booting stage of the plant (65 DAS).

The analyses of variance method as described by Cochran and Cox (1977) were followed for statistical analyses of the observed experimental data. The significance of different sources of variation was tested by "Error mean square method" following Fisher-Snedecor's F-test at probability level of 0.05.

\section{RESULT AND DISCUSSION}

\section{Growth attributes}

The different growth attribute of oats was measured at 90 DAS and statistically analyzed which have been presented in Table 1. An increasing trend in plant height of oats was found with the advancement of the age of the crop. The treatments under study did not show significant response towards the plant height of oats except at 90 DAS, where plant height was influenced significantly by various treatments applied in oats. Among the treatments, the highest plant height was measured in the treatment where 100\% NPK+ FYM@ 10 t / ha was applied along with ZnSO @20 kg / ha+ Borax @10 Kg/ha. This was significantly higher than the treatments having $100 \%$ NPK or $100 \%$ NPK + FYM @ 10 t/ha. Application of $100 \% \mathrm{NPK}+\mathrm{ZnSO}_{4} @ 10$ or $20 \mathrm{Kg} /$ ha along with FYM or without FYM showed significantly lower plant height as compared to 100\% NPK+ FYM @ 10 t/ha along with Borax @ 5 or $10 \mathrm{~kg} / \mathrm{ha}$ or $100 \%$ NPK+ FYM @ 10 t/ha along with Borax @ 5 or 10 $\mathrm{kg} / \mathrm{ha}$ and $\mathrm{ZnSO}_{4} @ 10$ or $20 \mathrm{~kg} / \mathrm{ha}$. The highest number of tillers/ plant was found at 90 DAS which was recorded in the treatment with $100 \%$ NPK+ FYM@10t/ha + ZnSO @ 20 kg/ha +Borax @ 10kg/ha (9.40). The treatment was statistically at par with the treatment $100 \%$ NPK+ FYM @ 10t/ ha + ZnSO @10 kg/ha + Borax @5kg/ha (9.20), the treatment 100\%NPK+ FYM @10t/ha + Borax@10kg/ ha (8.70) and the treatment of $100 \% \mathrm{NPK}+\mathrm{FYM}$ $@ 10 \mathrm{t} / \mathrm{ha}+$ Borax@5kg/ha (8.43). The use of 100\% $\mathrm{NPK}+\mathrm{ZnSO}_{4} @ 10 \mathrm{~kg} /$ ha showed the lowest number of tillers per plant (7.20). Application of $100 \%$ NPK+ FYM @ 10t/hain combination with $\mathrm{ZnSO}_{4}$ andBorax with their respective quantities facilitates higher number of tillers per plant than application of either $\mathrm{ZnSO}_{4}$ or Borax individually with $100 \%$ NPK+ FYM @10t/ha. Though the higher number of tillers per plant was recorded with higher quantities of $\mathrm{ZnSO}_{4}$ and Borax, no significant difference was found when compared with their lower quantities and similar trend was observation with dry matter $\left(\mathrm{g} / \mathrm{m}^{2}\right)$ (Agrawal et al. 2000 and Muhr et al. 2007).

The application of boron and zinc lead to an increase in the growth of oats, however, changing the nutritional value of the forage. Higher rates of absorption and accumulation of nutrients in plant tissues can be achieved with the application of 
Table 1: Effect of nutrient management on growth attributes of oats

\begin{tabular}{|c|c|c|c|}
\hline \multicolumn{4}{|c|}{ Growth attributes } \\
\hline Treatments & $\begin{array}{l}\text { Plant height } \\
(\mathrm{cm})\end{array}$ & $\begin{array}{l}\text { Number of } \\
\text { tiller/plant }\end{array}$ & $\begin{array}{l}\text { Dry matter } \\
\left(\mathrm{g} / \mathrm{m}^{2}\right)\end{array}$ \\
\hline $\mathrm{T}_{1}: 100 \%$ NPK $(80: 40: 20)$ & 119.3 & 7.35 & 433.7 \\
\hline $\mathrm{T}_{2}: 100 \% \mathrm{NPK}+\mathrm{FYM} @ 10 \mathrm{t} / \mathrm{ha}$ & 122.3 & 7.65 & 476.2 \\
\hline $\mathrm{T}_{3}: 100 \% \mathrm{NPK}+\mathrm{ZnSO}_{4} @ 10 \mathrm{~kg} / \mathrm{ha}$ & 118.9 & 7.20 & 451.7 \\
\hline $\mathrm{T}_{4}: 100 \% \mathrm{NPK}+\mathrm{ZnSO}_{4} @ 20 \mathrm{~kg} / \mathrm{ha}$ & 119.7 & 7.60 & 487.8 \\
\hline $\mathrm{T}_{5}: 100 \%$ NPK + FYM@10t/ha + ZnSO $@ 10 \mathrm{~kg} / \mathrm{ha}$ & 122.6 & 8.10 & 497.5 \\
\hline $\mathrm{T}_{6}: 100 \%$ NPK + FYM@10t/ha + ZnSO $@ 20 \mathrm{~kg} / \mathrm{ha}$ & 123.5 & 8.20 & 528.0 \\
\hline $\mathrm{T}_{7}: 100 \%$ NPK + Borax@5kg/ha & 120.2 & 6.70 & 478.5 \\
\hline $\mathrm{T}_{8}: 100 \% \mathrm{NPK}+$ Borax@10kg/ha & 122.1 & 7.90 & 532.0 \\
\hline T, $: 100 \%$ NPK + FYM@10t/ha + Borax@5kg/ha & 123.6 & 8.43 & 557.4 \\
\hline $\mathrm{T}_{10}: 100 \%$ NPK + FYM@10t/ha + Borax@10kg/ha & 123.9 & 8.70 & 561.5 \\
\hline $\mathrm{T}_{11}: 100 \%$ NPK + FYM@10t/ha + ZnSO $@ 10 \mathrm{~kg} / \mathrm{ha}+$ Borax@5kg/ha & 124.3 & 9.20 & 573.7 \\
\hline $\mathrm{T}_{12}: 100 \% \mathrm{NPK}+\mathrm{FYM} @ 10 \mathrm{t} / \mathrm{ha}+\mathrm{ZnSO}_{4} @ 20 \mathrm{~kg} / \mathrm{ha}+$ Borax@10kg/ha & 125.2 & 9.40 & 596.0 \\
\hline $\mathrm{S} \operatorname{Em}( \pm)$ & 4.59 & 0.34 & 6.99 \\
\hline CD at $5 \%$ & NS & 0.99 & 20.49 \\
\hline
\end{tabular}

FYM: Farm yard manure; NPK: Nitrogen, Phosphorus, Potassium.

higher dose boron and zinc which effect on different plant growth activities (Deise et al. 2012).

\section{Yield attributes}

The treatments were found to vary significantly among themselves with respect to number of panicles $/ \mathrm{m}^{2}$ in oats (Table 2). Among the treatments, combined application of $\mathrm{ZnSO}_{4}$ and Borax with their higher levels (i.e., $\mathrm{ZnSO}_{4} @ 20 \mathrm{~kg} / \mathrm{ha}$ and Borax $@ 10 \mathrm{~kg} / \mathrm{ha}$ ) along with 100 \% NPK+ FYM @10t/ ha produced higher number of panicles $/ \mathrm{m}^{2}$ (320). This was significantly higher than the combined application of $\mathrm{ZnSO}_{4}$ and Borax with their lower levels (i.e., $\mathrm{ZnSO}_{4} @ 10 \mathrm{~kg} / \mathrm{ha}$ and Borax @5 kg/ ha) along with 100\% NPK+ FYM @10t/ha (288.5). Application of 100\% NPK along with FYM @10t/ ha showed significantly higher number of panicles per meter $^{2}$ (256.0) over 100\% NPK alone. $\mathrm{ZnSO}_{4}$ or Borax with their higher levels (i.e., $\mathrm{ZnSO}_{4} @ 20 \mathrm{~kg} / \mathrm{ha}$ or Borax @10 kg/ha) along with 100\% NPK with or without FYM did not able to produce significantly higher number of panicles per meter ${ }^{2}$ than their lower levels with equivalent amount of NPK and FYM. No significant response was found from the treatments under study towards number of filled grains/ panicle of oats (Table 2).

However, the highest number of filled grains/ panicle was recorded in the treatment with $100 \%$
NPK+ FYM @10t/ha + ZnSO $@$ 20kg/ha + Borax $@ 10 \mathrm{~kg} / \mathrm{ha}(88.3)$ and the lowest number of filled grains/ panicle (74.2) was noticed in the treatment with $100 \%$ NPK as compared to other treatments. The treatments did not vary significantly in respect of percent filled grains of Oats. However, the highest filled grains percentage was recorded in the treatment with 100\% NPK+ FYM @10t/ ha + $\mathrm{ZnSO}_{4} @ 20 \mathrm{~kg} / \mathrm{ha}+$ Borax @ 10kg/ha (93.5 \%) and the lowest filled grains percentage was recorded in the treatment with $100 \%$ NPK application (84.3\%). The treatments under study vary significantly among themselves with respect to length of panicle in oats (Table 4.8). The highest panicle length was measured in the treatment with 100\% NPK+ FYM @ 10t/ha+ZnSO @ 20 kg/ha + Borax @ 10 kg/ha $(33 \cdot 10 \mathrm{~cm})$. This was significantly higher than $100 \%$ NPK application alone $(25.3 \mathrm{~cm})$ or application of 100\% NPK+ FYM @ 10t/ha $(27.3 \mathrm{~cm})$. in respect of test weight of oats seed. However, the highest test weight was observed in the treatment with 100\% NPK + FYM @ 10t/ha + ZnSO @ 20 kg/ha + Borax @ 10kg/ha (30.5 g) followed by 100\% NPK + FYM@ 10 t/ha + ZnSO $@ 10$ kg/ha + Borax @ 5kg/ ha $(30.3 \mathrm{~g})$. The lowest test weight was found in the treatment with $100 \% \mathrm{NPK}+\mathrm{ZnSO}_{4} @ 10 \mathrm{~kg} /$ ha $(287 \mathrm{~g})$. Chemical fertilizers, organic manure like FYM and different micronutrients like Zinc, Boron individually or combined has no significant 
Table 2: Effect of nutrient management on yield attributes of oats

\begin{tabular}{|c|c|c|c|c|c|}
\hline \multicolumn{6}{|c|}{ Yield attributes } \\
\hline Treatment & $\begin{array}{l}\text { No. of } \\
\text { panicles } / \mathrm{m}^{2}\end{array}$ & $\begin{array}{l}\text { No. of filled } \\
\text { grains/panicle }\end{array}$ & $\begin{array}{l}\text { Percent } \\
\text { Filled Grains } \\
(\%)\end{array}$ & $\begin{array}{l}\text { Length of } \\
\text { panicle }(\mathrm{cm})\end{array}$ & $\begin{array}{l}\text { Test weight } \\
\text { (g) }\end{array}$ \\
\hline $\mathrm{T}_{1}: 100 \%$ NPK $(80: 40: 20)$ & 216.0 & 74.2 & 84.34 & 25.33 & 28.83 \\
\hline $\mathrm{T}_{2}: 100 \% \mathrm{NPK}+\mathrm{FYM} @ 10 \mathrm{t} / \mathrm{ha}$ & 256.0 & 77.9 & 86.15 & 27.33 & 28.93 \\
\hline $\mathrm{T}_{3}: 100 \% \mathrm{NPK}+\mathrm{ZnSO}_{4} @ 10 \mathrm{~kg} / \mathrm{ha}$ & 245.3 & 75.1 & 84.66 & 29.73 & 28.70 \\
\hline $\mathrm{T}_{4}: 100 \% \mathrm{NPK}+\mathrm{ZnSO}_{4} @ 20 \mathrm{~kg} / \mathrm{ha}$ & 257.3 & 76.2 & 84.92 & 29.93 & 29.20 \\
\hline $\mathrm{T}_{5}: 100 \%$ NPK + FYM@10t/ha + ZnSO $@ 10 \mathrm{~kg} / \mathrm{ha}$ & 250.6 & 77.8 & 86.65 & 28.32 & 29.35 \\
\hline $\mathrm{T}_{6:} 100 \%$ NPK + FYM@10t/ha + ZnSO $@ 20 \mathrm{~kg} / \mathrm{ha}$ & 264.8 & 78.6 & 88.63 & 31.03 & 29.63 \\
\hline $\mathrm{T}_{7}: 100 \% \mathrm{NPK}+$ Borax@5kg/ha & 248.3 & 76.2 & 85.25 & 29.13 & 29.57 \\
\hline $\mathrm{T}_{8}: 100 \%$ NPK + Borax@10kg/ha & 262.6 & 76.8 & 86.98 & 30.11 & 29.70 \\
\hline T: $: 100 \%$ NPK + FYM@10t/ha + Borax@5kg/ha & 256.3 & 79.5 & 88.12 & 30.53 & 29.73 \\
\hline $\mathrm{T}_{10}: 100 \%$ NPK + FYM@10t/ha + Borax@10kg/ha & 275.2 & 80.8 & 88.95 & 31.87 & 29.83 \\
\hline $\begin{array}{l}\mathrm{T}_{11}: 100 \% \mathrm{NPK}+\mathrm{FYM} @ 10 \mathrm{t} / \mathrm{ha}+\mathrm{ZnSO}_{4} @ 10 \mathrm{~kg} / \mathrm{ha}+ \\
\text { Borax@5kg/ha }\end{array}$ & 288.5 & 85.4 & 92.19 & 32.52 & 30.36 \\
\hline $\begin{array}{l}\mathrm{T}_{12}: 100 \% \mathrm{NPK}+\mathrm{FYM} @ 10 \mathrm{t} / \mathrm{ha}+\mathrm{ZnSO}_{4} @ 20 \mathrm{~kg} / \mathrm{ha}+ \\
\text { Borax@10kg/ha }\end{array}$ & 320.0 & 88.3 & 93.51 & 33.10 & 30.52 \\
\hline $\mathrm{S} \operatorname{Em}( \pm)$ & 7.00 & 4.00 . & 3.06 & 1.29 & 0.91 \\
\hline $\mathrm{CD}$ at $5 \%$ & 21.00 & NS & NS & 3.79 & NS \\
\hline
\end{tabular}

Table 3: Effect of nutrient management on yield of oats

\begin{tabular}{|c|c|c|c|c|}
\hline \multicolumn{5}{|c|}{ Yield } \\
\hline Treatments & $\begin{array}{l}\text { Grain yield } \\
(\mathrm{t} / \mathrm{ha})\end{array}$ & $\begin{array}{l}\text { Straw yield } \\
\text { (t/ha) }\end{array}$ & $\begin{array}{l}\text { Biological } \\
\text { yield (t/ha) }\end{array}$ & $\begin{array}{l}\text { Harvest } \\
\text { index }(\%)\end{array}$ \\
\hline $\mathrm{T}_{2}: 100 \%$ NPK + FYM @10t/ha & 2.55 & 6.80 & 9.35 & 27.3 \\
\hline $\mathrm{T}_{3}: 100 \% \mathrm{NPK}+\mathrm{ZnSO}_{4} @ 10 \mathrm{~kg} / \mathrm{ha}$ & 1.98 & 6.23 & 8.21 & 23.7 \\
\hline $\mathrm{T}_{4}: 100 \% \mathrm{NPK}+\mathrm{ZnSO}_{4} @ 20 \mathrm{~kg} / \mathrm{ha}$ & 2.16 & 6.73 & 8.89 & 24.3 \\
\hline $\mathrm{T}_{6:} 100 \%$ NPK + FYM@10t/ha + ZnSO $@ 20 \mathrm{~kg} / \mathrm{ha}$ & 2.70 & 6.54 & 9.24 & 29.2 \\
\hline $\mathrm{T}_{7}: 100 \%$ NPK + Borax@5kg/ha & 2.13 & 6.62 & 8.75 & 24.3 \\
\hline $\mathrm{T}_{8}: 100 \%$ NPK + Borax@10kg/ha & 2.36 & 6.83 & 9.19 & 25.7 \\
\hline T: $: 100 \%$ NPK + FYM@10t/ha + Borax@5kg/ha & 2.87 & 6.95 & 9.82 & 29.2 \\
\hline $\mathrm{T}_{10}: 100 \%$ NPK + FYM@10t/ha + Borax@10kg/ha & 3.02 & 7.12 & 10.14 & 29.9 \\
\hline $\mathrm{CD}$ at $5 \%$ & 0.54 & 0.55 & 0.80 & NS \\
\hline
\end{tabular}

response on test weight of oats seeds. However, $\mathrm{ZnSO}_{4}$ or Borax at higher levels with or without FYM did not able to produce significantly higher straw yield over their lower levels. The study also showed that sole and combined application of $\mathrm{Zn}$ and $\mathrm{B}$ fertilizer increased the nitrogen and phosphorus content of the seeds. These results may be due to the beneficial effect of $B$ and $\mathrm{Zn}$ on metabolic processes and growth which in turn reflected positively on the yield attributes which were also in conformity with the findings of Joshi et al. (2007) and Malakar et al. (2009).

\section{Yield}

After harvesting the result observed that the yield of oats was influenced significantly by the treatments under study (Table 3). The highest grain yield was obtained in the treatment with 100\% NPK + FYM 
@10 t/ha+ZnSO @ 20 kg/ha + Borax @ 10 kg/ha (3.52 t/ha). This was statistically at par with the treatment of 100\% NPK + FYM @ $10 \mathrm{t} / \mathrm{ha}+\mathrm{ZnSO}_{4}$ @ $10 \mathrm{~kg} / \mathrm{ha}+$ Borax @ $5 \mathrm{~kg} / \mathrm{ha}$ (3:38 t/ha) and 100\% NPK + FYM @ 10 t/ha + Borax @ 10 kg/ha (3.02 t/ ha). Application of $\mathrm{ZnSO}_{4}$ or Borax separately at higher or lower levels with or without FYM gave no significant difference in respect of grain yield of Oats. A significant influence was found from different treatments in respect of straw yield of oats during field investigation. The highest straw yield was obtained from the treatment with 100\% NPK + FYM@ 10 t/ha + ZnSO @ 20 kg/ha + Borax@ 10 kg/ ha (7.93 t/ha). This was at par with $100 \%$ NPK + FYM @ 10 t/ha $+\mathrm{ZnSO}_{4} @ 10 \mathrm{~kg} / \mathrm{ha}$. The highest harvest index was found in the treatment having $100 \%$ NPK +FYM @ 10 t/ha+ ZnSO $@ 20$ kg/ha + Borax@ 10 $\mathrm{kg} / \mathrm{ha}(30.7 \%)$. This was followed by $100 \% \mathrm{NPK}+$ FYM@ 10 t/ha + ZnSO $@ 10$ kg/ha + Borax @ 5 kg/ ha $(30 \cdot 3 \%)$ and $100 \%$ NPK + FYM @ 10 t/ha + Borax @ $10 \mathrm{~kg} / \mathrm{ha}(29 \cdot 8 \%)$. Similar result was confirmed by Bhatt et al. (2000) and Khanday et al. (2009).

\section{Seed quality of Oats}

The chemical analysis of oats seeds and it was found that the treatments varied significantly among themselves in respect of percent nitrogen content in oats seeds (Table 4). The highest nitrogen content $(1.82 \%)$ in oats seeds was found in the treatment with 100\% NPK + FYM @10 t/ha + ZnSO @ 20 kg/ ha+ Borax @ $10 \mathrm{~kg} / \mathrm{ha}$. This was followed by 100\% $\mathrm{NPK}+\mathrm{FYM} @ 10 \mathrm{t} / \mathrm{ha}+\mathrm{ZnSO}_{4} @ 10 \mathrm{~kg} / \mathrm{ha}+$ Borax @ $5 \mathrm{~kg} / \mathrm{ha}(176 \%)$. However, these two treatments were at par with each other. Borax application both at lower and higher levels (@ 5kg/ha and 10kg/ ha, respectively) along with 100\% NPK and FYM $@ 10$ t/ha exhibited similar result in the protein content. Application of FYM@10t/ha +100 \% NPK had higher nitrogen content $(1.60 \%)$ than $100 \%$ NPK alone $(1.47 \%)$. Similar resulted was found in crude protein percent as of nitrogen content. Application of FYM @ 10t/ha with $\mathrm{ZnSO}_{4}$ or Borax with their higher as well as lower levels always showed higher crude protein percent than 100\% NPK solely (Rivera et al. 2008; Devi et al. 2019). Different nutrient management practices in oats for seed production had no significant response towards the length of oats seeds. The length of oats seeds ranged from $1.11 \mathrm{~cm}$ to $1.14 \mathrm{~cm}$ under various treatments. The longest length of seed was measured in the treatment having $100 \%$ NPK + FYM @ 10 t/ha + Borax@ 10 kg/ha $(1.14 \mathrm{~cm})$ and 100\% NPK+FYM@10 t/ha + ZnSO $@ 10$ kg/ha + Borax @ $5 \mathrm{~kg} / \mathrm{ha}(1.14 \mathrm{~cm})$. However, the shortest length of seed was found in the treatment with $100 \%$ NPK $(1.11 \mathrm{~cm})$. The treatments under study did not vary significantly among themselves in respect to breadth of oats seeds during field investigation. However, breadth of seeds range from 0.26 to $0.28 \mathrm{~cm}$ in nutrient management practices in oats. The higher

Table 4: Effect of nutrient management on seed quality of oats seeds

\begin{tabular}{|c|c|c|c|c|c|}
\hline Treatment & $\begin{array}{l}\text { Nitrogen } \\
\text { content }(\%)\end{array}$ & $\begin{array}{l}\text { Crude } \\
\text { protein } \\
(\%)\end{array}$ & $\begin{array}{l}\text { Seed } \\
\text { length } \\
(\mathrm{cm})\end{array}$ & $\begin{array}{l}\text { Seed } \\
\text { breadth } \\
\text { (cm) }\end{array}$ & $\begin{array}{l}\mathrm{L}: \mathrm{B} \\
\text { ratio }\end{array}$ \\
\hline $\mathrm{T}_{1}: 100 \%$ NPK $(80: 40: 20)$ & 1.47 & 9.17 & 1.11 & 0.26 & 4.25 \\
\hline $\mathrm{T}_{2}: 100 \%$ NPK + FYM @10t/ha & 1.60 & 10.00 & 1.13 & 0.26 & 4.38 \\
\hline $\mathrm{T}_{3}: 100 \% \mathrm{NPK}+\mathrm{ZnSO}_{4} @ 10 \mathrm{~kg} / \mathrm{ha}$ & 1.47 & 9.17 & 1.12 & 0.26 & 4.30 \\
\hline $\mathrm{T}_{4}: 100 \% \mathrm{NPK}+\mathrm{ZnSO}_{4} @ 20 \mathrm{~kg} / \mathrm{ha}$ & 1.59 & 9.92 & 1.13 & 0.27 & 4.28 \\
\hline $\mathrm{T}_{5}: 100 \% \mathrm{NPK}+\mathrm{FYM} @ 10 \mathrm{t} / \mathrm{ha}+\mathrm{ZnSO}_{4} @ 10 \mathrm{~kg} / \mathrm{ha}$ & 1.71 & 10.67 & 1.12 & 0.26 & 4.31 \\
\hline $\mathrm{T}_{6:} 100 \% \mathrm{NPK}+\mathrm{FYM} @ 10 \mathrm{t} / \mathrm{ha}+\mathrm{ZnSO}_{4} @ 20 \mathrm{~kg} / \mathrm{ha}$ & 1.75 & 10.92 & 1.13 & 0.27 & 4.21 \\
\hline $\mathrm{T}_{7}: 100 \% \mathrm{NPK}+$ Borax@5kg/ha & 1.51 & 9.42 & 1.12 & 0.26 & 4.32 \\
\hline $\mathrm{T}_{8}: 100 \%$ NPK + Borax@10kg/ha & 1.57 & 9.79 & 1.13 & 0.27 & 4.21 \\
\hline T9:100\% NPK + FYM@10t/ha + Borax@5kg/ha & 1.68 & 10.50 & 1.13 & 0.27 & 4.27 \\
\hline $\mathrm{T}_{10}: 100 \%$ NPK + FYM@10t/ha + Borax@10kg/ha & 1.74 & 10.90 & 1.14 & 0.27 & 4.21 \\
\hline $\mathrm{T}_{11}: 100 \%$ NPK + FYM@10t/ha + ZnSO $@ 10 \mathrm{~kg} / \mathrm{ha}+$ Borax@5kg/ha & 1.76 & 10.98 & 1.13 & 0.28 & 4.14 \\
\hline $\mathrm{T}_{12}: 100 \% \mathrm{NPK}+\mathrm{FYM} @ 10 \mathrm{t} / \mathrm{ha}+\mathrm{ZnSO}_{4} @ 20 \mathrm{~kg} / \mathrm{ha}+$ Borax@10kg/ha & 1.82 & 11.38 & 1.14 & 0.28 & 4.19 \\
\hline$\underline{\operatorname{SEm}( \pm)}$ & 0.07 & 0.45 & 0.04 & 0.02 & 0.35 \\
\hline $\mathrm{CD}$ at $5 \%$ & 0.21 & 1.32 & NS & NS & NS \\
\hline
\end{tabular}


seed breadth of Oats was found more than the other treatments, where combined application of $\mathrm{ZnSO}_{4}$ and Borax both at their higher (i.e., @ $20 \mathrm{~kg} / \mathrm{ha}$ and $10 \mathrm{~kg} / \mathrm{ha}$, respectively) and lower (i.e., @ $10 \mathrm{~kg} / \mathrm{ha}$ and $5 \mathrm{~kg} / \mathrm{ha}$, respectively) rates was done. Length: Breadth ratio of oats seeds was not influenced significantly by various treatments studied in this experiment. However, a range of 4.30 to 4.38 was observed in length: breadth ratio of oats seeds. The highest length: breadth ratio of 4.38 was found in the treatments where organic manure like FYM was added @ 10 t/ha along with 100\% NPK and the lowest (4.14) length: breadth ratio was found in the treatment with 100\% NPK + FYM @10t/ha $+\mathrm{ZnSO}_{4}$ $@ 10$ kg/ha+Borax@ 5 kg/ha. (Tobiasz and Bobrecka 2006; Karwasra et al. 2007)

\section{CONCLUSION}

From these summarized experimental results it may be concluded that the application of application of $\mathrm{ZnSO}_{4}$ and Borax at their higher rates (20 and 10 $\mathrm{kg} / \mathrm{ha}$, respectively) along with 100\% NPK + FYM @ $10 \mathrm{t} /$ ha exhibited the best results in respect of growth attributes, productivity and seed quality of oats seed with comparable with the application of $\mathrm{ZnSO}_{4}$ and Borax at their lower levels i.e. @ $10 \mathrm{~kg}$ and 5kg per ha along with FYM @ $10 \mathrm{t} / \mathrm{ha}$ and 100\% NPK gave lowest values.

\section{REFERENCES}

1. Anonymous, 2010-11. Directorate of Economics and Statistics, Department of Agriculture and Cooperation, pp. 64-65.

2. Agrawal, R.K., Verma, S.C. and Singh, K.K. 2000. Influence of nitrogen and moisture regimes on growth and yield of oat cultivars. Range Management and Agroforestry, 21(2): 206-212.

3. Bhat, M.D., Singh, K.N., Amarjit Bali and Shah, M.H. 2000. Grain yield of oat (Avena sativa) as influenced by sowing time and nitrogen levels under temperate conditions of Kashmir. Indian Journal of Agronomy, 45(1): 199-204.

4. Cochran, W.G. and Cox, G.M. 1977. Experimental Designs. Asia Publishing House, Calcutta, pp. 95-191.

5. Devi, U., Panghaal, D., Kumar, P., Sewhag, M. and Kumar P. 2019. Effect of nitrogen fertilizers on yield and quality of oats: A Review. International Journal of Chemical Studies, 7(2): 1999-2005.
6. Joshi, Y.P., Verma, S.S. and Bhilare, R.L. 2007. Effect of Zinc levels on growth and yield of oat. Forage Research, 32(4): 238-239.

7. Karwasra, R.S., Kumar, Y., Kumar, V. and Kumar, A. 2007. Integrated nutrient and cutting management. Forage Research, 33(1): 63-64.

8. Khanday, B.A., Samoon, A.R., Waseem Raja, Jhangir Khanday and Bahar, F.A. 2009. Integrated nutrient management for seed production of oat under temperate condition of Kashmir. International Journal of Agricultural Sciences, 5(1): 145-147.

9. Malakar, B. Mondal, S., Bandopadhyay, P. and Kundu, C.K. 2009. Response of forage oat (var. OS-6) to nitrogen and phosphate fertilizers in the new alluvial zone of West Bengal. Journal of Crop and Weed, 5(2): 36-38.

10. Muhr, R.M., Grant, C.A., May, W.E. and Stevenson, F.C. 2007. The influence of nitrogen, phosphorus and potash fertilizer application on oat yield and quality. Canadian Journal of Soil Science, 87: 459-468.

11. Rivera Reyes, J.G., Cortez Beheza, E., Peraza Luna, F.A., Serratos Arevalo, J.C., Posos Ponce, P., Guevara Gonzalez, R.G., Torres Pacheco, I., Guznan Maldonodo, S.H. 2008. Agronomic traits associated to yield and quality in oat seeds. Asian Journal of Plant Sciences, 7(8): 767-770.

12. Singh, M.V. 2009. Benefit of micronutrients enrichment in seed. Indian Journal of Fertilizer, 5(4): 19-20.

13. Tobiasz Salach, R. and Bobrecka Jamro, D. 2006. Effects of nitrogen fertilizer on the yield, protein content and yield components of oat. Biulety nInstytutuHodowli-iAklimatyzacji Roslin, 239: 41-47.

14. Deise Dalazen Castagnara1, Alexandre Krutzmann, Tiago Zoz, Fábio Steiner, Ana Maria Conte e Castro, Marcela Abbado Neres, Paulo Sérgio Rabello de Oliveira. 2012. Effect of boron and zinc fertilization on white oats grown in soil with average content of these nutrients. R. Bras. Zootec., 41(7): 1598-1607.

15. Goldbach, H.E., Yu, Q. and Wingender, R. 2001 Rapid response reactions of roots to boron deprivation. Journal of Plant Nutrition and Soil Science, 164(2): 173-181.

16. Malta, M.R., Furtini Neto, A.E. and Alves, J.D. 2002. Efeito da aplicação de zinco via foliar na síntesede triptofano, aminoácidos proteínas solúveisem mudasde cafeeiro. Brazilian Journal of Plant Physiology, 14(1): 31-37.

17. Jena, J. Palai, J.B. and Dash, G.K. 2019. Nutrient management for sustainable oat production - a review. Forage Res., 45(3): 165-172. 
